EESTI NSV TEADUSTE AKADEEMIA TOIMETISED 1953. II k., nr. 2

ИЗВЕСТИЯ АКАДЕМИИ НАУК ЭСТОНСКОИ ССР 1953. ТОМ II, 스 2

\title{
EESTI JA VENE ELEMENDID EESTI NSV KIRDEOSA ELANIKKONNA MATERIAALSES KULTUURIS
}

\section{A. MOORA}

Vene ja eesti rahvas on sajandite kestel olnud sōbralikus vastastikuses läbikäimises. Selle tulemusena on mõlemad rahvad teineteiselt omandanud rohkesti mitmesugust kultuurivara. Iseäranis on eesti rahva kultuur suuresti rikastunud vene rahvalt saadud varade kaudu. Erilist huvi vene ja eesti rahva põliste suhete käsitlemisele pakub mölema rahva piirilähedaste alade uurimine. Siin võime jälgida mitte ainult vastastikust kultuurielementide üleminekut, vaid ka nende rahvaste vahetut kokkupuutumist, etniliste seganähtuste tekkimist. Siin võime kõige otsesemalt selgitada neid tegureid, mis soodustasid vastastikust kultuurivarade omandamist.

Uheks niisuguseks huvitavaks kokkupuutealaks on Eesti NSV kirdeosa, kus vene ja eesti elanikkond on sajandite vältel asunud mitte ainult kōrvuti, vaid osalt ka üksteise seas. Seepärast vōttiski NSV Liidu Teaduste Akadeemia Etnograafia Instituut koos Eesti NSV Teaduste Akadeemia asutustega 1952. aastal selle piirkonna üheks uurimisalaks.

Tsaari-Venemaa ja kodanliku Eesti tingimustes ei pööratud vene ja eesti rahva vastastikuste suhete küsimusele mingit tähelepanu, neid ignoreeriti sihilikult. Ei osutatud huvi ka nimetatud piirkonna omapäraste kultuuriliste ja etniliste nähtuste vastu. Neid märgiti vaid pooleldi pilgates kui kurioosumeid. Eesti etnograafilise materjali kesksesse hoiukohta, ENSV TA Etnograafia Muuseumi on tol perioodil sellelt alalt kogutud vaid üksikuid juhuslikke esemeid, mōningaid ühekülgseid teatmeid ja mõnedest küladest ehituste plaane, kuid ilma igasuguste elu-oluliste andmeteta. Täiesti puudusid andmed, mis oleksid valgustanud mõlema rahva vastastikust suhtlemist ja selle ajalugu.

1952. aastàl korraldatud ekspeditsioonil tuli seepärast asuda materjalide kogumisele algusest peale. Sellel aastal kogutud aines käsitleb Jōhvi rajooni nelja lōunapoolsesse külanõukogusse (Vaikla, Katase, Iisaku ja Jõuga) kuuluva 7 kolhoosi ala 22 küla (Jōuga, Sörumäe, Tammetaguse, Koldamäe, Kaleva, Lipniku, Tärivere, Taga- ja Ees-Varesmetsa, Iisaku I ja II, Kasevälja, Allika, Sälliku, Vaikla, Pootsiku, Alajōe, Katase, Uusküla, Kuru, Kauksi, Lõppe ja Metsküla (Vaabu)).

Kõik nimetatud külad kuulusid XIX sajandi lōpuni, osalt isegi veel XX sajandi algul alles mōisatele. Nende elanikkond koosnes talurentnikestperemeestest, kandimeestest ja sulastest. Talurentnikud maksid mōisale raharenti. Kandimehed, keda siin nimetati tündrimaameesteks (vene keeles полудёнки), tegid tegu 3 päeva nädalas. Alajōe kaluriküla elanikud olid suures enamuses endised väikeste linnade, nagu Paide, Rakvere, Valmiera vöi Gdovi kodanikud. 
Talude müük möisate poolt algas 1890. aasta paiku, 1913. aastaks oli see pōhiliselt lõpetatud. Vōrreldes muu Eesti alaga, polnud talude krundid siin suured. Nende suurus oli tavaliselt 14-30 ha, ainult üksikud talud ulatusid $50-60$ ha-ni. Olgu märgitud, et talumaast moodustas suurema osa mets, karjamaad ja sood. Pōllumaad oli taludel 3-15 ha.

Pärast ostu püüdsid kōik talud oma pōlde suurendada, harides üles metsaja karjamaid. Vaadeldavale piirkonnale on iseloomulik, et siin suurem osa talusid hiljem jagunes pärijate vahel. Selle tagajärjel killunesid nn. vanade külade talud juba käesoleva sajandi algul paljudeks väikemajanditeks. Enne kollektiviseerimist oli enamikul majanditest pōldu vaid 3 ha ümber.

1920-ndatel aastatel tekkis kodanliku maaseaduse alusel endistele mõisamaadele rida uusi asulaid nagu Kasevälja, Allika, Lipniku ja Kaleva. Ka need koosnesid suures enamuses väikemajapidamistest, kuna maapuuduse tõttu ja kulaklusele .odava tööjōu kindlustamiseks jagati mõisamaad pisikesteks kruntideks.

Peipsi järve äärses Alajōe külas omasid umbes 50 kaluriperet hoopis vähe maad või olid täiesti maata. Ka teised järveäärsed külad koosnesid kodanliku diktatuuri perioodil suures enamuses kas maata või vähese maaga majapidamistest.

1940. aastal andis Nōukogude vōim siingi maata ja vähese maaga talurahvale maad:

1949. a. sai murranguliseks aastaks kogu Eesti talurahvale. Sel aastal toimus talurahva massiline üleminek endistelt mahajäänud individuaalmajapidamistelt kollektiivsele majapidamisele. 1949. aastal ühines ka kirjeldatava ala talurahvas kolhoosidesse. Alguses asutas iga küla omaette pōllumajandusliku artelli, kuid alates 1951. aastast, pärast väikeste kolhooside ühinemist, töötab uritud alal 7 kolhoosi: „Tee Kommunismile”, ,Sotsialismi Tee”, "Kalev”, „Kalevipoeg”, „Uue Jōuga”, „Esimene Mai" ja „Peipsi Laine”. Neist „Esimene Mai”, kuhu kuuluvad Alajōe, Katase ja Uusküla, on kalurikolhoos, „Peipsi Laine”, kuhu kuuluvad Kuru ja Kauksi küla, on segatootmisega kolhoos ühe kaluri- ja kahe pôllumajandusbrigaadiga. Teised kolhoosid on kōik puhtpöllumajanduslikud artellid.

Nimetatud kolhoosidel on maad igaühel 1200-2052 ha, millest aga ainult $138-340$ ha on põllumaad. Igasse kolhoosi kuulub 50 - 90 perekonda. Vōrreldes kollektiivsete majapidamiste produktsiooni endiste individuaalmajandite toodanguga, leiame selles teatavaid struktuuri muudatusi: lina siinsed kolhoosid enam ei kasvata, kartuli kõrval kasvatatakse rukist ja teisi teravilju. Märgitav on eriti aianduse, köögiviljakasvatuse ja ühisloomakasvatuse kiire areng.

Peatume küsimusel elanikkonna etnilisest koosseisust. Välja arvatud järveäärsete külade (Alajōe, Katase, Uusküla ja Kuru) rahvas, peavad kōigi teiste külade elanikud endid pölisteks eestlasteks. Tegelikult aga on kaardile (joon. 1) ristikestega märgitud külades varem elanud segaelanikkond. Nende külade rahvast nimetati varem ,poluvertsikuteks", missugune nimetus ulatus isegi kirjandusse !. Seda nimetust peab aga rahvas ise solvavaks. Käesolevas ülevaates nimetatakse endise segaasustusega külade elanikke kohaliku peakeskuse järgi lisaku elanikeks või Iisaku eestlasteks ja vastavaid külasid Iisaku küladeks.

Peipsiäärsetest küladest on Alajōe ja Uusküla vene elanikkonnaga külad, kus leidub vaid üksikuid eesti perekondi. Katase ja Kuru on segaelanikkonnaga külad, kusjuures Katases on praegu enamuses venelased, Kurus

1 Ю. Т русман, Иеахские полуверцы в Эстляндской губернни. Временннк Эстляндской губернин. Кннга II, Ревель 1895. 
aga eestlased. Pärast Suurt Isamaasőda on üksikuid vene ja ingeri perekondi asunud ka mõnesse eesti külasse.

Enne kui teha kokkuvōtet etniliste ja etnograafiliste nähtuste hilisemast arenemisest, esitame kōnesoleva ala kohta mōned ajaloolised andmed.

Vaadeldav ala oli XIII sajandil Virumaa kōige idapoolsema kihelkonna

Alutaguse - naabruses. Hiljem kuulus ta Jōhvi kihelkonda. 1866. aastal

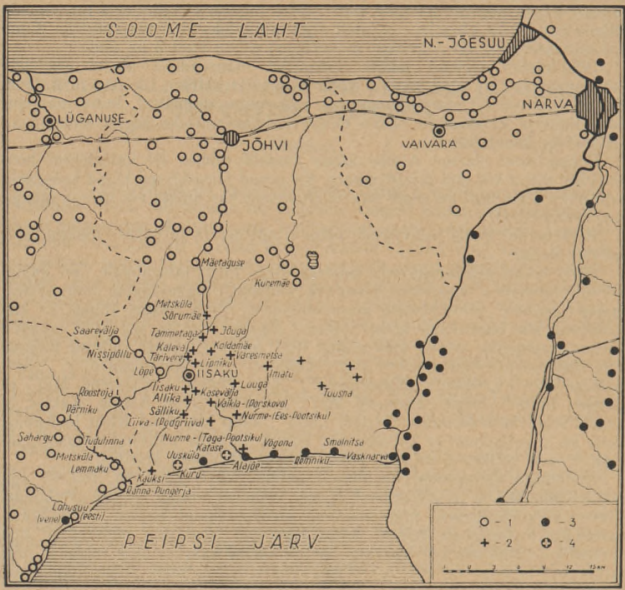

Joon. 1. Jōhvi rajooni kaart. Eraldi on ăra tähendatud asulad, kust ekspeditsiooni poolt koguti andmeid: $I$ - pölised eesti külad: 2 - Iisaku eestlaste külad: 3 - vene külad: 4 - eesti-vene segaelanikkonnaga külad.

kujundati see aga ühes Viru-Jaagupile kuulunud Tudulinnaga iseseisvaks Iisaku kihelkonnaks.

Endise Virumaa ala jaguneb oma looduslike tingimuste poolest kahte erinevasse ossa. Pōhjapoolne, Soome lahe äärne osa on kōrgem. Selles piirkonnas oli juba alates vähemalt viimase aastatuhande keskelt e. m. a. maaharimisest ja karjakasvatusest elatuv rahvastik. Nimetatud ajast kuni taanisaksa feodaalsete anastajate sissetungini XIII sajandil võib selles Virumaa osas tihedalt leida eesti hõimudele omaseid arheoloogilisi mälestusmärke.

Kagupoolne osa Virumaast, Peipsi järve rannik koos teatud piirkonnaga sellest pôhja pool on madal. See ala oli pärastjääaegse perioodi alguses üle ujutatud järve poolt, mis hiljem taandus lõuna suunas. Oleujutuse jälgedena laiuvad siin laialdased sood, mille üle kerkivad piklikud paralleelselt 
kulgevad liivased vallseljakud, endised järve rannamoodustised. Neile liivastele seljakutele keset soid ja parimetsa ongi tekkinud praegune asustus.

Arheoloogiliste andmete pōhjal asustati see vana Virumaa lõunapoolsem osa vōrdlemisi hilja - alles m. a. XII sajandil. Siia ilmuvad novgorodipärased kääpad, mis oma kujult, ehituselt ja inventarilt järsult erinevad muu Virumaa ja ka kogu muu Eesti kalmetest. Praegu teadaolevate andmete jārgi leidub neid kääpaid Jôuga, Pühtitsa ja Kuru küla juures, Kurust ulatuvad nad veel edela poole kuni Vadi külani Avinurmes. Hiljuti avaldas V. V. S e d ov neist kääpaist Novgorodimaa loodeosades saadud arheoloogiliste ja antropoloogiliste materjalide uurimise tulemused ${ }^{2}$. Sedov eraldab nende seas kolm gruppi, millest ühte peab slaavi-, teist vadjapäraseks ja kolmandat segarühmaks. ENSV TA Ajaloo Instituudi noorema teadusliku töötaja Karin Marki suulistel andmetel, kes on uurinud Jôuga ja Pühtitsa kääbaste luustikke, kuuluvad need Sedovi segatüübi hulka.

Põhja-Eesti kohta käiv vanim asustusajalooline allikas, XIII sajandi esimeselt poolelt pärinev Taani Hindamise Raamat ei maini külasid lôunapoolses Alutaguses. Nähtavasti alistasid taani-saksa anastajad selle hõreda asustusega piirkonna põhjapoolsetest põlistest eesti küladest mõnevõrra hiljem.

XVI sajandi keskelt säilinud väheste kirjalike dokumentide järgi otsustades oli vaadeldava ala keskosas ülekaalus eesti asustus, Peipsi rannikul, vähemalt selle idapoolses osas, elasid aga venelased.

XVIII sajandi allikad, eriti rootsiaegsed Alutaguse môisate maanimistud, mainivad venelasi selle piirkonna lōunaosas - Rannapungerja ja Pootsiku (nüüdses Nurme) külas, aga ka Pagari mõisa alal, mis hõlmas Jõuga, Tammetaguse, Sôrumäe ja teisi naabruses olevaid külasid. Tuleb aga arvestada seda, et need allikad nimetavad elanikke venelasteks mitte ainult keele tunnuse järgi, vaid ka usulise kuuluvuse järgi. Seetōttu vổidi venelasteks nimetada ka vene-õigeusulisi ingerlasi ja vadjalási.

Alutagusesse elama asunud venelased on ōige varakult ristitud luteri usku, mis nähtub sellest, et XVII sajandil saadetakse Jőhvi pastorile eeskiri vene keele ōppimiseks, et ta Iisaku venelastele saaks jutlustada nende emakeeles.

Alates XVIII sajandist täiendab kirjalike allikate teateid juba rahvatraditsioon. Rahvapärimuste pōhjal peab osa lisaku eestlasi end põlisteks kohalikeks elanikeks. Teine osa teab aga rääkida oma esivanemate tulekust siia mujalt, pärast sōdasid või põgenikena kas mõisnikkude vägivalla või soldatiks andmise eest. Rahvapärimused, mis on üles kirjutatud 1894. aastal $^{3}$, räägivad perekondadest, kelle esiisad olevat asunud siia elama 6-10 pōlve tagasi Novgorodist, Pskovist või Narva jōe tagant. 1940. ja 1952. aastal üleskirjutatud pärimused nimetavad elanikke veel tulnukatena Eidovist ja Poolamaalt.

Nagu nähtub 1952. aastal üksikute külade elanike kohta kogutud andmeist, säilitasid venelased oma keele kōige kauemini Vaiklas (end. Porskovos). Teistes külades eestistusid nad varemini. Seetōttu mäletatakse vene elanikke praegu peaasjalikult ainult Vaiklast.

Möödunud sajandi lõpul, alates talude müümisest, on märgata ka eesti elementide juurdevoolu mujalt, Virumaa lääneosast, samuti ka Tartumaa pōhjapoolsetest va!dadest. Et juurdetulijaid eestlasi siin peeti võõrasteks, näitab see, et neid siin on kohati hüütud tšuhnadeks ${ }^{4}$. Vene naisi on käesoleva sajandi alguseni abiellumise kaudu juurde tulnud Vaiklasse, kõnele-

2 В. В. Седов, Антропологинеские типы населения северо-западных земель Великого Новгорода. Краткне сообення Института этнографни, вып, -XV, 1952, стр. 72 н сл.

з Ю. Т р у с м а н, mainitud teos, Ik. 5 ja edasi.

4 Andmed saadud "Uue Jôuga" kolhoosist Koldamäe külast, Ekateriina Teedlalt. 
mata Peipsiäärsetest küladest. Nad on olnud pärit Gdovi maakonnast, vene küladest Narva jōe ülemjooksul ja isegi Pskovist.

Kogutud andmete järgi on Iisaku ümbruses veel praeguse keskealise pōlve vanaisadest ja -emadest paljud kodus omavahel rääkinud vene keelt. Oldse mōistab elanike vanem pölv, 50 -aastased inimesed ja vanemad, suurelt jaolt vene keelt. Kuid ainult osal on see oskus pärit kodust, vanematelt, teistel on see omandatud läbikäimisest kohalike venelastega, osalt ka kooli kaudu. Kolmekümneaastased möistavad vene keelt kõige vähem, mis on tingitud kodanliku diktatuuri aegsest poliitikast, mis vene keelt kõigiti tagasi tôrjus. 1952. aastal saadud teadete kohaselt räägivad veel praegugi môned $70-80$-aastased vanad isekeskis meelsamini vene keelt. Nende keel aga on omapärane segu vene ja eesti keele sõnadest ja grammatilistest vormidest. Truusman märgib, et 1890-ndate aastate algul on Porskovos (nüüdses Vaiklas), vaatamata kooli ja kiriku tugevale eestistavale mōjule, lauldud veel vene rahvalaule. Kuid seda on tehtud juba vargsi ja häbelikult, et ōpetajad ja härrased ei kuuleks 5 .

Uuritud piirkonna külad olid möödunud sajandini väikesed, koosnedes kuni talude müümiseni ainult vähestest taludest. Sama arv talusid oli seal nähtavasti juba kaua enne seda. Nii näiteks oli Tärivere külas XIX sajandil 9 talu ja niisama palju oli neid juba 1712. a.

Pärast talude väljaostmist jagunesid need varsti pärandamisel poegade vahel kas pooleks vơi mitmeks. Olgu tähendatud, et talude nii üldist jagamist poegade vahel me mujal Eestis ei kohta, see esineb üldiselt veel vaid Eesti kagupiiril ja selles näib ilmnevat vene mõju.

Talude jagamise tagajärjel pärijate poegade vahel oli külades enne kollektiviseerimist terveid rühmi samanimelisi naaberperemehi. Esitame näitena Vaikla (end. Porskovo) küla, mida teiste külade elanikud nimetavad ,,vene nurgaks"- vōi ,poolvenelaste külaks". Praegu on Vaiklas umbes 35 kolhoosipere majapidamist (endist üksikmajandit). Viimase 30 aasta jooksul ei ole Vaiklas enam uusi majapidamisi juurde tekkinud. Kuid möödunud sajandil oli selles külas ainult $6-7$ talu, mis asetsesid môlemal pool teed üksteisest eemal. Vaikla küla elanike perekonnanimedeks olid: Karp, Subka, Fedka, Nimvitski, Sevlinski, Rebina, Sellik ja Peep. Peebud on siia elama asunud hiljem, tulles lisakust, kust nende esiisa olevat mõisniku poolt välja aetud. Karbi suguvōsa on pärit Paleku talust. Perekonna traditsiooni järgi on nende esiisa siia tulnud Poolamaalt (võrdle Paleku - поляк). Hiljem on see suguvõsa hargnenud Paleku, Kamaroki ja Griina Karpideks, kes omakorda jagunesid mitmeks perekonnaks; nii näiteks on nende üheks haruks nn. Juurina omad.

Igal talul oli hiljem, kodanliku diktatuuri ajal, oma ametlik nimi, kuid rahvas seda ei tarvitanud ega tundmudki. Karpide talud asetsesid köik ühelpool teed, $3-4$ talu ühes rühmas, endise ühise, hiljem ärajagatud talu maal. Nii on 7 Griina Karpide väikest majandit tekkinud ühest 47-tiinulisest talust. Viis Fedka nimelist perekonda kandsid kōik hüüdnime „Molotoki omad".

Vaikla külas oli ka venekeelseid kohanimesid, näiteks Kosternitsa mägi, Griina mägi, Babina mägi. Kodanliku diktatuuri ajal muudeti suurem osa lisaku venekeelseid perekonna- ja kohanimesid eestipärasteks.

Samasugust üleminekut ühelt keelelt teisele, kuid vastupidises suunas, näeme Peipsiäärsetes vene külades. Ka Katase küla venelaste hulka on segunenud eestlasi. Nii oli perekond Stšeberini vanaisa eestlane, perekonnanimega Söber. See nimi mutus hiljem Seberiks ja viimaks Stšeberiniks. Samasuguse muudatuse on läbi teinud ka perekonnanimi Selkovski, mille algkujuks on eesti Salk.

5 Ю. Т русман, mainitud teos, Ik. 5. 
Uusküla on nime järgi otsustades tekkinud teistest rannaküladest hiljem. Traditsioonikohaselt on üks küla rajajatest olnud Garnovide esiisa, päritolult eestlane, kes läks üle ap.-öigeusku ja vene keelele. Et selle, nagu naaberküla Katasegi elanikud vốrsuvad vähestest algseist perekondadest, näitab asjaolu, et neis mitmeid perekondi nimetatakse ühise hüüdnimega куст Гарновых, куст Бондаревых јпе.

Uuritaval alal näeme seega kaht paralleelset etnilise assimileerumise protsessi. Rannaäärsetes külades, välja arvatud Kuru ja Kauksi, toimus ja toimub praegu eestlaste venestumine. Mujal aga, kus rahvas tegeleb põllumajandusega, toimus vastupidine protsess: venelased omandasid ajajooksul eesti keele.

Need mōlemad protsessid kiirenesid kapitalistlikkude suhete arenemisega. Rannaäärsed kalurikülad seisid pōlistest aegadest peale tihedas kontaktis Narva jôe ülemjooksu ja Peipsi idaranniku vene küladega. Tuleb mainida, et nende peipsiăärsete külade vene kalurid läksid juba ammu üle arenenumale kutselisele kalandusele. Nende artellides kujunesid ka juba XIX sajandi esimese poole lõpuks kapitalistlikud suhted. Rannaäärsetesse küladesse asunud eestlased omandasid venelastelt mitte üksnes nende arenenumat tööoskust ja täielikumaid tootmisriistu, vaid liitusid ka nende töö organisatsiooni, artellidesse ja astusid seega kōige tihedamatesse sidemetesse venelastega. Väga olulist osa etendas siin ka öigeusk, millega mitmeti olid seotud venelaste elu-olu ja kombestiku omapärased nähtused.

Seevastu vene talupojad, kes asusid eesti vōi segarahvastikuga küladesse, olid sunnitud mitte üksnes alluma möisate töökorraldusele, vaid pidid ka elama asuma üksteisest lahus olevaisse taludesse. Peale selle pidid vene talupojad õige vara, nähtavasti juba XVII sajandil, vastu võtma luteriusu. Baltimaade luteriusulises ümbruses oli vene-ốigeusk venelastele üheks oluliseks rahvuse tunnuseks. Usuvahetusega see tunnus kadus. Kahtlemata mōjus luteriusu kirik kaasa ka selleks, et protestantlikud venelased kaotasid oma keele ja assimileerusid teiste kohalikkude protestantidega, s. o. eestlastega. Seda iseloomustab näiteks nende ridade autori poolt kuuldud ütlus ühe mehe venelasest naise kohta, et .,ta ristis end eestlaseks".

Segarahvastiku väiksearvuline jōukam kiht - makodanlus - assimileerus teistest varem. Selle kihi klassihuvid sundisid teda liituma arvukama eesti maakodanlusega. Hiljem levitas kodanlus ühes valitseva möisnikeklassiga arvamist venekeelse kehvema rahva ebavördsusest, sundides seega viimast end lahti ütlema oma keelest ja rahvuslikest iseärasustest. Selle ebavôrdsusetunde igandeid võib veel praegugi leida üksikute lisaku eestlaste juures.

Kuidas avaldub lisaku elanikkonna mitmesugune etniline koosseis ja selles toimunud muudatused tema ainelises kultuuris?

Iisaku eestlaste peamisel elatusalal- - pôllunduses - ei ole muu Eesti alaga võrreldes märgata suuri lahkuminekuid, kuigi üksikuid erinevusi on olemas.

Iisaku metsarikkal alal măletab rahvas niihästi ale kui ka kütise tegemist. Künniriistadest kasutati ja kasutatakse kartulimuldamiseks kohati veel praegugi lühikeste sirgete aistega, kurgedeta harkatra. See adratüüp on levinud idapoolses Eestis, eriti kaguosas. Läänepoolsele Virumaale oli see tüüp üldiselt vōōras. Oksikuil puhkudel on lisakus tarvitatud kōvera künni- ehk rauapuuga atra, mida kohtame ida pool Narva jôge. Atra nimetatakse kohati ka vene keeles eestikeelse nimetusega аркадра. Vaiklas ja Kurus nimetati teda vene keeles ругачулка, teistes külades ругач, рыгачи, aga ka coxa, või маленькая соха. Ǎketest tarvitati raamäket.

Viljakoristamine ja heinaniitmine toimus aastat kolmkümmend tagasi veel käsitsi. Oli kasutusel $\mathrm{ja}$ on metsaheinamail veel praegugi kasutusel 
sirge löega vikat. Kesk- ja Lääne-Eesti pulga ja karguga kõverat lütt ei mäletata.

Rukkivihud pandi hakkidesse, milles aga oli vähe vihke (ca 10 ) ja mida nimetati viisik, vene keeles килос. Rukist rabati nagu Pōhja-Eestiski vihke vastu seina lüües. Rabamispinki, mida Lõuna-Eestis kasutati, siin ei tunta. Rukkirehte peksti kuotidega, mida vene keeles nimetati приузы. On andmeid, et vanasti tuulati lisakus vilja seda kühvliga visates, hiljem tuulati aga nagu mujalgi Eestis, sarjaga, rehealuse väravas.

Karja karjatati, paiguti viimase ajani, küla poolt ühiselt. Ka praegu saadavad mõnes külas kolhoosnikud oma lehmad ühise karjasega metsa.

Iisaku rahvas tarvitab ka vene keeles mitmeid eestikeelseid põllunduslikke ja karjanduslikke termineid. Näiteks vaod on ka vene keeles вагуши. Koort (siin smetana) hoiti kirnus, vene keeles кирнуша. Piima võeti kaasa lähkris (siinses vene keeles хляга). Tuleb öelda, et üldiselt on terminoloogia nii vene kui ka eesti keeles väga puudulik. Jääb mulje, nagu oleksid vanad venekeelsed terminid unustatud ja eestikeelseid pole jōutud omandada.

lisaku rahva toidus on palju ühist vene rahva toiduga ja vene valmistamisviisidega. Sellele sarnasusele osutati eriti Vaikla küla suhtes, kuigi Vaikla elanikud ise tegid vahet oma ja vene toidu vahel. Nii näiteks kinnitati Vaiklas, et nemad on alati toitu valmistanud pliidil, venelased aga ahjus. Tegelikult aga ilmnes, et kogu lisaku alal on valmistatud ja valmistatakse veel praegugi üsna mitmeid toite ahjus. Tuleb märkida, et kogu uuritud alal valmistatakse palju mitmesuguseid pirukaid, nii leiva- kui saiataignasse. Leivataignaga tehti liha-, kaalika- ja hapukapsapirukaid. Levinud on ka seente- ja kalapirukad, mis ilmsesti osutab vene mōjule.

Omapäraseks nähtuseks on siin mitmesugused munaroad, nagu munakärss (praetud munad), munasupp, munavōi (hakitud keedetud munad segatud võiga). Samu toite kohtame ka teistes Kirde-Eesti rajoonides ning ka ingerlaste juures.

Kaerakilet, mis siin on üldiselt tuntud, nimetatakse kisse 1. Vanasti on valmistatud nn. guša't, vene keeles ryщa, mida mäletavad ainult veel üksikud vanad inimesed. Uhmris tõugatud suurmaile lisati herneid ja ube ja hautati potiga ahjus pehmeks. Dali järgi ${ }^{6}$ oli гуща, густая похлебка end. Novgorodi, Pskovi ja Tveri kubermangus otradest ja hernestest puder. Teiselt poolt aga öeldi Iisakus, et see olnud uhmris tõugatud otradest keedetud puder. Sama seletus ryщa kohta anti ka 1953. a. juunis Gdovi ümbruses. Kuremäe ümbruses olevat kuusad'eks nimetatud uhmris tôugatud suurmaid.

Selle ala iseärasuseks oli ka kanepipiima valmistamine, mis mujal Eestis väga harva esines. Aastat 60 tagasi tehti seda veel vaid Vaiklas-Porskovos. Mujal nähtavasti oli see juba unustatud. Ahjus kuivatatud kanepiseemned tōugati uhmris puruks ja hōõruti siis kausis piimale. Vett lisades söödi seda kanepipiima pudru ja leivaga. Isegi hapukapsasuppi on keedetud kanepipiimaga. Karjakasvatamise arenemisega kadus see komme ja säilis paiguti veel vaid kehvikute majapidamises, kus lehmi üldse ei olnud või kus oli ainult üks lehm.

Kama valmistati vene moodi kaerajahust. Kui aga lisakus sellest jahust keedeti paksu putru, siis nimetati seda ka vene keeles eesti nimetusega кама путру.

Väga levinud on kohupiim, mida siin nimetatakse venepäraselt vorok ehk vorong. Seda valmistatakse ka venemoeliselt ahjus. Kohupiimast tehakse tänaseni nn. vorongi matska't (Gdovi ümbruses on varemalt kohupiima

6 В. И. Даль, Толковый словарь жнвого великорусского языка, ПетербургМосква 1912, том I. 
nimetatud амачка, Leningradi oblastis veega segatud kohupiima помачка). Seda valmistati kohupiimale mune, koort ja vōid lisades ning ahjus potis küpsetades. Jōhvi rajooni kesk- ja lōunaosas on amatska'ks nimetatud kohutatud piima, millele oli segatud rõōska piima ja mida söödi lusikaga kartuli ja leiva kõrvale. Nimetus on kadumas, kuigi see toit esineb veel praegugi.

Samal viisil tehakse kartulipudrust ka kartulimatskat. Mōlemaid matskasid söödi paistekakkudega lepjoška’dega, mida igal hommikul ahju paistel

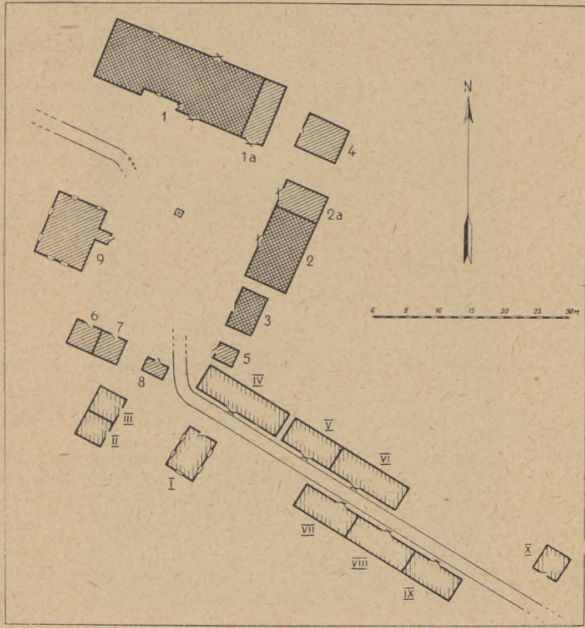

Joon. 2. Kolhoos „Uue Jõuga”, Koldamãe kũla. Ohest talust vŏrsunud kahe venna hoonete paigutuse skeem. $I-3-$ isatalust pärinevad hooned (ristiviirutusega; $I a$, $2 a, 4-9-$ vanema venna poolt ehitatud hooned (pốtkiviirutusega); $I-X-$ teise venna hooned, ehitatud piki karjatänavat (ääreviirutusega).

küpsetati. Selle paistekakuga ammutati potist matskat, öeldes, kui teisi seda sööma sunniti: mak, mak! On huvitav, et ,mak, mak” öeldi lastele ka veel siis, kui oli juba üle mindud eesti keelele. "Mak" tuleb ilmsesti vene sõnast макать.

Külade praeguses plaanis, välja arvatud Alajōe, ei ole vene jooni märgata. Mõnedel andmetel olid Jõuga küla talud enne küla pōlemist XIX sajandi keskel asetsenud küla endisel kohal venepäraselt. Ka Tärivere 
külas olid talud XIX sajandi keskel olnud tihedasti koos kahelpool laia külateed, kusjuures elumajad asetsesid otsaga tee poole.

Oksikute talude õueplaan lisaku külades on üldiselt sama, mis mujalgi Eestis. Hooned on paigutatud tavaliselt ümber nelinurkse lahtise oue. Sel. les ōueplaanis aga toimus muudatusi pärast talude jagamist pärijate vahel. Sageli ehitas isa küll poegadele (vahel isegi kolmele) ühise elumaja, igale perele eraldi sissekäiguga, kuid kõrvalhooned ehitas iga poeg endale eraldi. Alati aga jäi isa rehi poegadele ühiseks kasutamiseks.

Maa kokkuhoidmiseks püstitasid pärijad tihti oma hooned endisele koduõuele, mistōttu endine avar õu ehitati hooneid täis. Niisugust pilti näeme näiteks Taga-Varesmetsa külas. Skeem (joon. 2), näitab talu plaani, kus noorem vend on endale ehitanud eraldi hooned piki talu karjatänavat.

Olenevalt traditsioonist, jagada võimalikult kõigile poegadele maad, killunesid talude maad kapitalismile omase alatise maapuuduse tōttu kääbus kruntideks ja nende õued muutusid kitsasteks ning plaanilt ebakorrapärasteks.

Ka uute majapidamiste rajamisel tingis maa kokkuhoiu vajadus loomulikult õuede vähendamist, mida näeme nn. asunikkude juures.

Ou piirati siin, nagu mujalgi Eestis, tavaliselt ainult madala rōhtsaist lattidest või püsti lippidest tehtud taraga. Kinniseid planktarasid ja kōrgeid väravaid ei olnud.

Vaatamata vähesele maale on siin elumajad üldiselt vōrdlemisi avarad ja hästi ehitatud. Nad on tihti vooderdatud ja värvitud. Kui maja on vooderdamata, siis vähemalt aknad on ilustatud valgeks vôi siniseks värvitud piirdelaudadega.

Eluhooneid uuendati suhteliselt tihti. Seletatakse seda ühelt poolt sellega, et siin on mets käepärast, teiselt poolt aga sellega, et siinné parimets annab halba, vähese vastupidavusega puitu. Mõned $70-80$-aastased inimesed elavad oma eluajal samas talus juba kolmandas elumajas. Nende mälestuses oli aja jooksul toimunud ka hoonete plaanis rida muudatusi. Eriti kiiresti hakkasid ehitused muutuma pärast talude ostmist, alates käesoleva sajandi teisest kümnendist.

Erilistest tehnilistest detailidest on vanadel ehitustel säilinud omapärane kirvega raiutud kuuetahuliste palgiotstega nurk - koerakaela kaba (joon. 3). Seda leiame mōnel vanal rehielamul, aga ka vanadel aitadel. Sää raselt tahutud seina nurka leidub samuti Jōhvi rajooni pōhjaosas, aga ka ingerlaste ja vadjalaste ehitustel. Sarnast nurka mäletatakse ka Gdovii ümbruses vanadel aitadel. Niisuguste nurkadega vanadel aitadel on katus olnud ka sarikateta. Seda kannavad roovilatid, mille otsad toetuvad palkidest laotud villudele. Uuematel aitadel, nagu teistelgi ehitustel, on sari katega katus.

Palkidest viil on siinsetel ehitustel, eriti kōrvalhoonetel, väga tavaline. Niisugused palkidest laotud viiluga ehitused esinevad ka Kagu-Eestis ja Peipsiäärsetes vene külades, aga ka Valgevenes ja Novgorodi oblastis. samuti ka ingerlaste, vadjalaste ja karjalaste ehitustel. Mujal Eestis esineb säärane viil harva ja peamiselt heinaküünidel.

Kogu käsitletaval alal, välja arvatud kahes kalurikülas, Alajōel ja Uus. külas, oli vanaks elamuks kas kambriga või kambrita rehetuba. Vanad inimesed mäletavad, et nende lapsepõlves esines rehealusega elurehtede kõrval ka rehealuseta maju. Maja võis koosneda kas rehetoast ja kambrist ilma rehealuseta, vôi oli rehetuba ja rehealune, aga polnud kambrit. See olenes muidugi pere majanduslikust seisukorrast. Samal ajal kui mitmel pool möisa kandimehed vöi tündrimaamehed elasid ainult rehetoas, kus kuivatati ka vilja ja peksti rehte, oli peremeeste majadel juba peale rehetubade 2 kambrit. Kohaliku maakodanluse eraldumisega ilmuvad möödunud sajandi 
lôpus juba üksikud suuremad ja avaramad elumajad, mis olid ehitatud kas rehest eraldi või rehielamutena, millele jõukamad peremehed peale mōisa poolt lubatud 2 kambri ehitasid oma kulul veel 2 kambrit lisaks. Keskmiku rehielamus oli hilise ajani rehetuba, $1-2$ kambrit ja rehealune. Säärase jaotusega elumajad olid Iisakus tüüpilised kuni XX sajandi alguseni ja neist on mõned säilinud tänaseni. Nende seas võib eraldada kaht tüüpi. Oht neist võib pidada üldeestiliseks. Seda iseloomustab kambrite vahetu liitumine

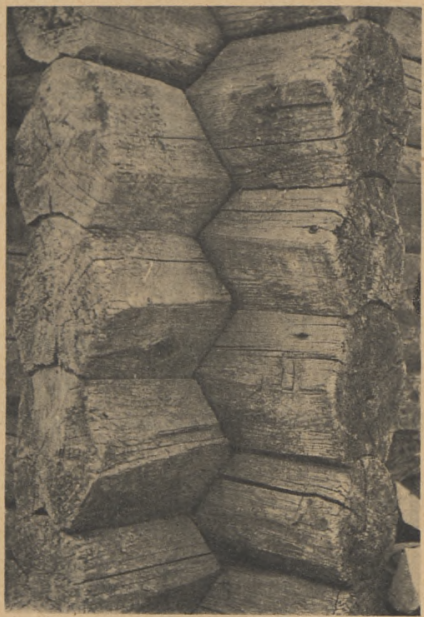

Joon. 3. Kirvega raiutud (kandiline) nurk nn. koerakaelakaba, esineb vanadel ehitustel.

rehetoale. Seda tüüpi kohtame nii Jöhvi rajooni põlistes eesti külades kui ka lisaku piirkonna külades.

Teine tüüp oli rahvamälestuste järgi varem üldine endistes vene elanikega külades, nagu Vaiklas ja Täriveres. Seda kohtame ka Jõugal, Koldamäel, Kurus ja Kauksis. Selle tüübi iseloomustavaks omaduseks on see, et siin oli kambrite ja rehetoa vahel pikk, läbi kogu maja laiuse ulatuv kitsas „koridor”, mis pliidi sisseehitamisega hiljem muudeti köögiks. Vanad inimesed mäletavad, et näiteks Vaiklas ja Täriveres sellest „koridorist”, nagu nad nüüd seda nimetavad, läks uks ühelt poolt tuppa, kus oli suur ahi, ja teiselt poolt rehetuppa, milles samuti oli ahi ja kus kuivatati vilja. Täriveres ei 

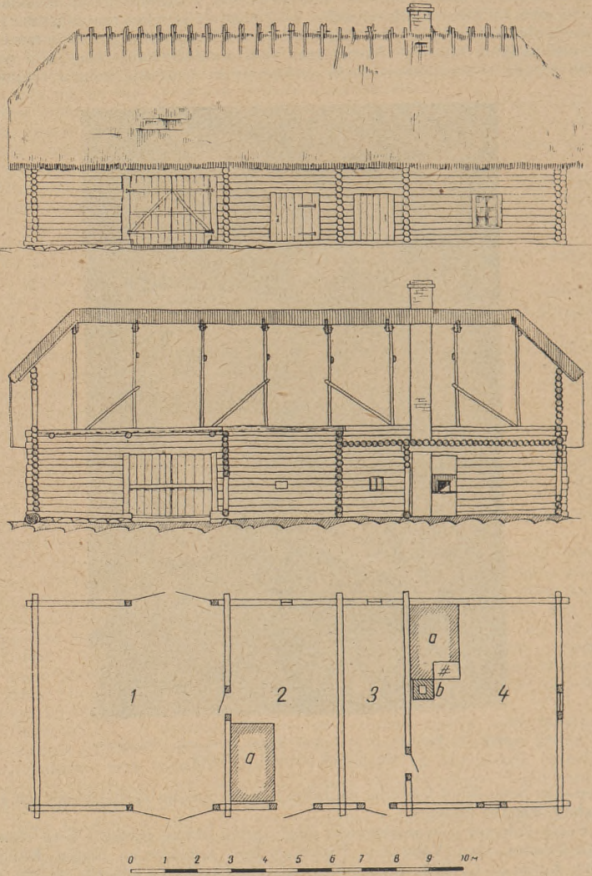

Joon. 4. Vana rehielamu ühes plaaniga, Kauksi külast (end. Baumani talu). ENSV TA Etnograafiamuuseumi jooniste kogust, EJ $68: 4)$. I - rehealune, 2 - rehetuba, 3 - koda, 4-kamber. 
olnud niisugustel majadel otsas rehealust. See on seletatav väikese saagiga, mis peksti samas rehetoas. Vaiklas oli aga säärase jaotusega majadel ka rehealune. Vanade inimeste mälestuste järgi on nende lapsepōlves säärast koridori vene keeles kutsutud сени. Ahjuga suurt kambrit olevat kutsutud изба. Seeni'st olevat üks uks viinud rehetuppa ja teine $i z b a$ 'sse. Täriveres on säärast koridori kutsutud общий. Hiljem, nagu öeldud, ehitati sellesse koridori pliit ja siis keedeti siin toitu, samuti lehmadele sulpi (vene keeles сульпу), leib aga küpsetati kambri (izba) ahjus.

Etnograafiamuuseumi fondides on säärast tüüpi elumaja plaan 1928. aastast Kauksi külast (joon. 4). Samasuguse plaaniga elamuid on varemini olnud ka lisakus ja teistes külades.

86-aastane teadeteandja Jaan Palm (end. nimega Ivan Putkin) Kuru külast mäletab, et tema lapsepõlves läks nende elumajal uks ōuest rei'sse,

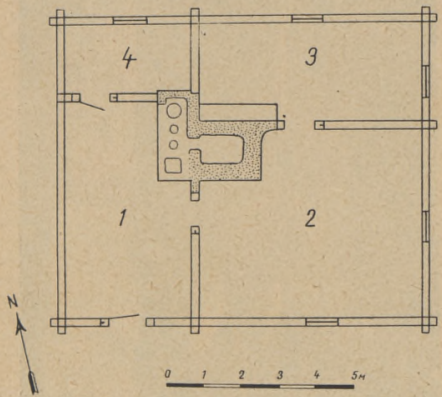

Joon. 5. Sälliku küla, end. Pahvali elamu, ehit. 1894, a. (ENSV TA Etnograafiamuuseumi kogudest, EJ 159:5/16).

s. o. rehetuppa, sellest edasi uks ühelt poolt kambrisse ja teiselt poolt rehealla. Niisugune oli esimest tüüpi rehielamu. Hiljem, tema noormehepōlves olevat ehitatud teist tüüpi maja, kus uks läinud väljast seeni'sse ja sealt ühelt poolt izba'sse ja teiselt poolt rei'sse. Hiljem ehitatud veel izba'le magamistuba kōrvale ja selle nimetus olnud nii eesti kui vene keeles tagakamber. Kolmas, kõige hilisem maja on ehitatud juba rehest lahus. Iisakus hakati rehest lahus elumaju ehitama aastatel $1870-1880$.

Vanemates rehest lahus ehitatud majades (joon. 5) on osalt veel märgata vana seeni ja izba jaotusega plaani, milles seeni aga juba on jaotatud kaheks, köögiks ja sahvriks. Hilisemates rehest lahus ehitatud elumajades esineb venepärane ruumide jaotus vaid Peipsi ääres vene ja segarahvastikuga külades. Seal koosnevad elumajad seenist ja eluruumidest, kusjuures seenist viib teine uks majale otsa ehitatud katusega karjaaeda (двор), milles on loomalaut. Säärase plaaniga maju on ka rannaäärsetel eestlastel. Pōllumaaga majanditel oli niisuguse elumaja juures olemas veel eraldi ait ja rehi. Venetüübilistel majadel on alati põranda all kelder - подпол, kuhu viib toast luuk, uuematel majadel viib uks keldrisse väljast ja siis nimeta- 
takse seda juba norpeб. Madal kartulikelder on ka lisaku ehitustel köögi pōranda all.

Iisaku uuemate elumajade viilud sarnanevad oma ehitusviisilt vene elumajade viiludega nii Peipsiäärsetes külades kui ka kaugemal Pskovi ja Novgorodi oblastis ja mujal. Neil on nimelt viil laudadega kinni löödud kas kalasaba vôi muus sarnases mustris. Viilu all, otse seina ülaäärel on kitsas

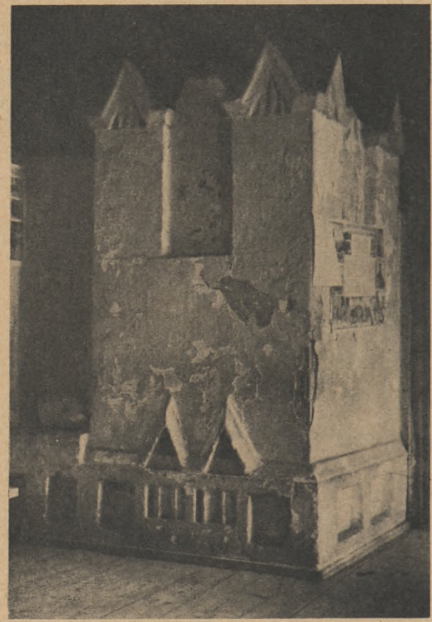

Joon. 6. Ahi kolhoosi „Sotsialismi Tee" kantseleis, Pootsiku külas. Ehitatud 1910 , a.

katus, karniis. Säärast viilu kutsutakse lisakus puhas räästaalune (vene keeles чистый ящик).

Kirjeldatud ala elanike eluruumid on üldiselt väga puhtad. Pōrand on valge, harva värvitud. Ta on hästi puhtaks küüritud ja nii eestlastel kui venelastel tihedasti kaetud porrandariietega. Sageli on eestlastel toanurga ülaosas riiul, suurtes tubades seisab mõnel pool nurgas, puhtasnurgas või puhaspooles kapp küünaldega. Selle nurga tähistamine meenutab vastava vene majade nurga (siin vene keeles большой угол) kaunistamist. See on veel käesoleva sajandi algul olnud tavaline ka lisaku luteriusulistel eestlastel. 
lisaku elumajade üheks omapäraseks nähtuseks 'on nende ahjud. Vana rehetoa ahi oli keriseta. Teadeteandjate kinnitust mööda on kerisega ahjusid hakatud ehitama uuematesse elumajast eraldi ehitatud rehtedesse. Teati rääkida, et vanasti olnud izba ja seeniga majas ahi vene moodi puust alusel. Praegustes vanemates venepärase plaaniga elumajades (näiteks Kuru külas) on ahi toas ukse kõrval, suuga ukse poole. Mujal Iisakus on uuemates majades ahi ehitatud maja keskele, nii et ta oma eri külgedega ulatub igasse tuppa. Praegu on enamasti ühes toas kas ahju või soojamüüri kōrval lesku ehk lezenka. See tekkis siin möödunud sajandi lõpul. Varemini ehitati see telliskividest, uuemates majades aga on see vahel ehitatud isegi kahhelkividest. Kōige uuemates ehitustes leskut enam ei ole.

Iisakus käesoleva sajandi esimesel poolel ehitatud elumajade ahjud on väga suured, nad omavad omapäraseid karniise ja tühemeid ning astanguid (joon. 6). Sageli on neil karniiside taga madal ahjupealne, kuhu saab ahjukapist üles ronida, et end seal soojendada. Need ahjud on enamasti ehitatud kohapeal tuntud Sōrumäe pottsepa Lepiku ja ta õpilaste poolt. Olgu veel märgitud, et siin on ahju siibri nimetus sama, mis vene keeles: juška.

Elumajadest eraldi ehitatud rehed seisavad, niipalju kui ruum óuel lubab, tuleohtlikkuse pärast alati teistest hoonetest eemal. Iisakus nähtud rehed on kolme tüüpi. Esimesse kuuluvad rehed, mille tagaküljel rehetoa ja rehealuse sein on ühel joonel. Rehe esiküljel aga on rehetuba rehealusest kitsam ja rehetoa ette jääb lahtine katusealune ukseesine ehk ukseedine. Teist tüüpi rehtedel on rehetuba rehealusest mõlemalt poolt kitsam; rehetoast eemaleulatuvad katusenurgad toetuvad sammastele. Kolmandat tüüpi rehtedel on rehetuba ja rehealune ühelaiused. Viimast tüüpi rehtesid esineb harva. Teist tüüpi rehed on levinud ka Jôhvi rajooni pōhjaosas, Valgevenes ja Lätis; samasuguseid rehtesid on Etnograafiamuuseumis leiduvail andmeil ka Leningradi oblastis.

Suuremal osal rehtedest on kahekordsed parred, mida Eesti NSV alal tuleb lugeda idapoolseks nähtuseks. . Niisugused parred esinevad Valgevenes ja Leningradi oblastis ning samuti Soomes.

Vanimaid ehitusi tuleb kõige sagedamini ette aitade hulgas. Tihti näeb aita, mis oma olemasolu kestel on juba kolmandale kohale üles laotud. Mōnede aitade iga arvatakse ulatuvat vähemalt 150-le aastale. Nagu eespool öeldud, on neil aitadel kirvega raiutud nurk, palkidest viil ja katus, mis oma rooviga toetub viiludele. Sissekäik on neil ühest otsast ja suurus kõigil ühtlane, $4,2 \times 5$ meetrit. Niisuguseid väikseid aitu on tavaliselt perel olnud 2, üks riiete, teine viljaaidaks. Uhed neist on körgemad, teised madalamad. Mônedel ulatuvad küljepalgid ja otsakatus ette, teistel ulatub viil ette, nagu näitel joon. 7. Säärase viiluga aitu on teada KaguEestist, Valgevenest ja Karjala-Soomest. Teisel aidatüübil on sissekäik küljelt, katuse räästas ulatub siin ette ja toetub kas aida eesküljel olevatele sammastele või väljaulatuvatele ülemistele küljepalkide otstele. Ka mônel niisugusel vanemal aidal on nurgad kirvega raiutud kuuetahuliste otstega.

Vanemat tüüpi laut on kolmeosaline. Keskel on karjaaed vôi sara, ühel pool otsas on loomalaut, teisel pool lamba- ja sealaut, osa on mõnikord ka hobusetalliks. Selline sega-laudahoone jaotus on vanim ja esines üle terve Eesti.

Peipsiäărsetes külades on, nagu öeldud, karjaaed laudaga ehitatud vahetult maja otsa. Mujal külades seisab laut alati elumajast kaugel, üle ōue, kas maja vastas vōi küljel.

Iisaku elanikke eraldas XIX sajandil muust Virumaast nende rõivastuski. Jisaku meeste särk oli nii lõikelt (püstkrae ja eest külje poole viltu kinni- 
sega) kui kandmisviisilt (pükste peal) venepärane. Siin ei kantud tol ajal mujal Eestis üldiselt levinud lühikesi villaseid pükse, vaid püksid olid pikad ja linased või takused. Naised kandsid mitte Pōhja-Eestile iseloomulikke käiseid, triibulist seelikut ja kirivööd, vaid punasega tikitud särki. Särgi peal kanti setu umbrüü taolist krassik'ut, mis varem oli valge ja hiljem värviline, ja laia, riidest vōi ,letitud”, s. t. palmitsetud kitsast vööd. Abielunaiste peakatteks oli samal ajal vene povoinik, mis siin aga noorikule esimest korda pähe pandi eestipärase linutamise kommetega.

Nii mehed kui naised kandsid möödunud sajandi keskel ülirōivana valget linast rüüd (eest lahtikäiv puusavoltideta pikk-kuub, joon. 8). Rüü ilustati rinna eest ristpistes kaunistusega. Iisaku rüüd olid hoo-

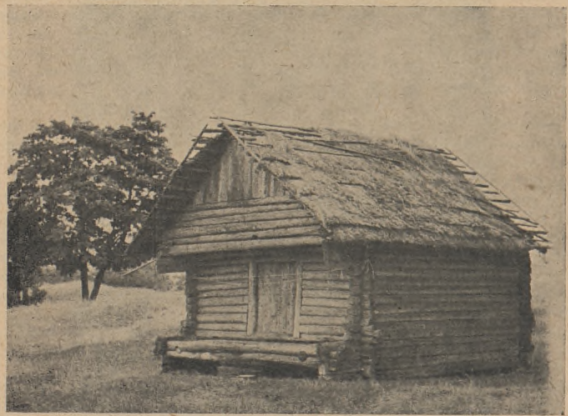

Joon. 7. Vana ait. „Peipsi Laine” kolhoos (Kuru küla).

pis teistsuguse lõikega kui Virumaa ja muu Eesti meeste linased rüüd.

On veel mälestusi ja muuseumikogude pōhjal andmeid rahvarōiva osadest, mis seda ala seob vanema vadjapärase rahvarõivaga. Nii on Iisakus naised kandnud linikutaolist peaehet povoi'd, mis sarnanes vastavale vadja naiste sabana'le. Samuti on andmeid, et naised on seljataga kandnud pōlletaolist riidetükki, mis on omane mordva naiste rõivastusele. Iisakus on naised kandnud ka kõrvarōngaid, aga mujal Eestis seda kommet polnud. Eesti naistele tavalist rinnaehet, sổge, on kantud ainult Iisaku pōhjapoolsetes äärekülades. Vaiklas ja segarahvastikuga külades sōlge kantud ei ole.

Oldiselt oli ja esineb ka praegu lisaku naiste käsitöös venepäraseid ornamente ja värvitoone (loomamotiive, eredaid värve), mis seda ala eraldab muust Virumaast. Iisaku käsitööde ja rahvarōiva ornamendi ja värvitoonide mõju on aga märgata Iisaku naabruses olevates põliseesti külades.

Rahvarồivas kadus kandmiselt nii veneląstel kui eestlastel möödunud sajandi viimasel veerandil.

Siinsetel vene ja eesti küladel on mitmeid ühiseid jooni kombestikuski. Nii on siin tuntud noorte neidude käsitööōhtute korraldamine, nn. subritkad 


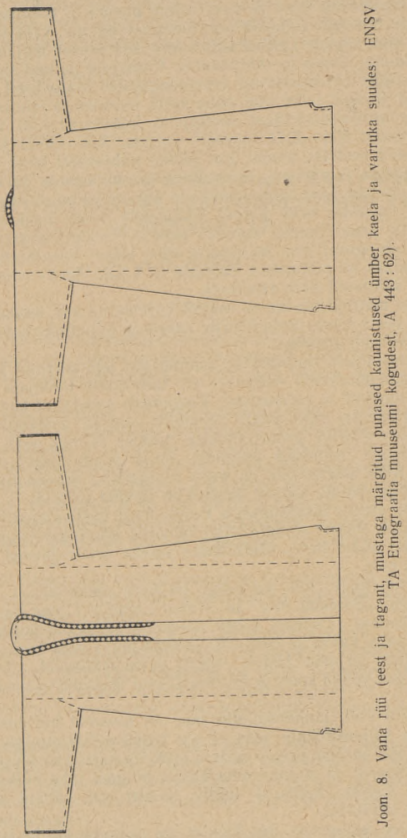


ehk ehalkäimised. Palju ühiseid kombeid on esinenud ka vanemal ajal nii tootmisalases elus (nagu karjakasvatamisega seotud kombed) kui ka perekondlikus e'u-olus (näit. pulmakombeis).

Kuigi kogutud andmed on esialgsed ning vajavad täiendamisi ja täpsustamist, võib nende alusel ometi juba nüüdki öelda, et käesoleva ala elanikkond moodustab vene ja eesti rahva piiriäärse nähtusena omapärase etnilise grupi. See pole juhuslik ega üleminev nähtus, vaid tal on oma kestev ajalugu, oma aegade jooksul kujunenud iseärasused majanduselus, materiaalses kultuuris, keeles ja rahvaluules. Viimaseid polnud siin kahjuks vōimalik puudutada. Olemasolevad arheoloogilised, ajaloolised ja etnograafilised andmed lasevad sellel alal näha mitut kultuuri ja etnilist kihti. Arheoloogilised ja antropoloogilised materjalid kõnelevad siin vene-vadja või -ingeri asustusest XII-XIII sajandil. Hiljem, XIV-XVII sajandil tungib siia põhja poolt eestlasi, samal ajal jätkus nähtavasti idast aegajalt venesoome elementide juurdevool. Selle tōendiks on asjaolu, et etnograafilises materjalis esinevad vene kultuurimōjude kōrval vadja-ingeri komponendid. XVIII-XIX sajandil, eriti pärast Pōhjasōda tuleb Iisakusse uusi vene asunikke, kelle peakeskuseks kujuneb eeskätt Vaikla-Porskovo. Seoses sellega kasvab etnograafilises materjalis vene mõju. Venelased, kelle peamiseks tootmisalaks oli pōllundus, kaotasid XIX saj. lōpuks oma keele, kalurikülades aga säilitasid selle täielikult.

Ajalooliste materjalide kõrval koguti kirjeldatud alal loomulikult ka andmeid vene ja eesti rahva vastastikuste suhete ja mōjutuste kohta kaasaegses, nōukogude perioodi elu-olus.

Püüdes kapitalismi tingimustes summutada lepitamatuid klassivastuolusid, ōhutas natsionalistlik kodanlus eri rahvustest töötajate vahel vaenu, ebavôrdsuse tundeid ja sallimatust. Vaatamata sellele, et kapitalismi tingimustes mürgitati eri rahvustega rajoonide elanike vastastikuseid suhteid kodanlik-natsionalistliku propagandaga, püüdes sellega eesti ja vene naaberkülade rahvast üksteisest eraldada, püsis nende vahel ometi sōbralik läbikäimine. Selle avalduseks on need vastastikku omandatud ühised kultuurinähtused ja môjud, millest eelpool on toodud näiteid.

Nōukogude võimu taastamisega Eestis need vastastikused suhted muutusid pōhjalikult. Pääsis vōidule kōigi rahvaste võrdōiguslikkus, Venelasi ja eestlasi seovad nüüd üheks sõbralikuks pereks nende ühised huvid ïhises sotsialistlikus töös.

Uuritud alal, nagu juba märgitud, on kaks segakolhoosi, vene ja eesti liikmeskonnaga (.Esimene Mai” ja „Peipsi Laine”). Uhine töö nendes artellides viib mőlemad rahvused kôige tihedamasse vastastikusesse kontakti. Selleks aitab palju kaasa ka eestlaste vanema pōlve vene keele oskus. Iisaku 7 -aastases koolis on vene lastele loodud paralleelklassid. Uheskoos koolis käies, ühiselt osa võttes kooli ja ühiskondlikest üritustest kasvavad nad ühiseks pereks.

Nii vene kui eesti kolhoosnikute seas on tõusnud hariduslik tase. Kui vanema põlve kolhoosnikute seas ei ole keskkooliharidusega inimesi, siis nüüd õpivad juba paljude perede noored kesk- ja mõned ka kổrgemates ōppeasutustes. Kolhoosid on andnud oma noorte hulgast juba hulk traktoriste ja teisi ōppinud töölisi. Kolhoosi juhtiv kaader on käinud end täiendamas erialastel kursustel.

Nii kunstiline isetegevus, mis kasvab iga aastaga, kui ka kehakultuur ja sport koondab mōlemast rahvusest noori ühistesse üritustesse. Kolhoosinoorus ligineb üksteisele mitte ainult oma kolhoosi, vaid ka külanôukogu ja veelgi laiemates piirides.

Kapitalismi aja rahvuslikus kultuuris domineeris kodanlik-natsionalistlik kultuur. See kultuur halvustas teisi rahvusi ja isoleeris end teistest. Vene ja 
eesti rahva sotsialistlik kultuur aga mōjub vastastikku viljastavalt, mis avaldub naiste käsitöös, kodukaunistamises, rahva toitudes jne.

Esitatud materjal, olles kogutud üheainsa lühikese ekspeditsiooniaja kestel, on veel mitmeti lünklik. See nõuab edasist täiendamist ja täpsustamist. On vaja koguda ka vōrdlusmaterjali naabrusest, nii eesti kui vene elanike't. Iisaku eestlaste ja naabruses olevate vene külade kultuurisuhete pildi täiendamiseks tuleb siia veel lisada selle ala keeleteaduslikkude ja rahvaluuleliste andmete uurimise tulemusi. See kōik on edasise töö ülesandeks. Eesti NSV Teaduste Akadeemia
Ajaloo Instituut
Saabus toimetusse

20. IV 1953

\title{
ЭСТОНСКИЕ И РУССКИЕ ЭЛЕМЕНТЫ В МАТЕРИАЛЬНОИ КУЛЬТУРЕ НАСЕЛЕНИЯ СЕВЕРО-ВОСТОЧНОЙ ЧАСТИ ЭСТОНСКОЙ ССР
}

\author{
A. X. MOOPA
}

Pезюме

В статье подводятся предварительные итоги работы по сбору этнографических данных на северо-востоке Эстонской ССР (в южной части Иыхвиского района), проведенной в 1952 году, Всего было обследовано 22 деревни.

Население этих деревень (за исключением одной - Алайыэ) состояло до конца XIX века из крестьян-дворохозяев, арендовавших свон хутора у местных помещиков, а также из батраков, работавших как на дворохозяев, так и на помещиков. В состав рыбацкого населения причудской деревни Алайыэ входило значительное число мещан из городов Гдова, Раквере, Пайде, Валмиера и др. За время с 1890 по 1913 год большинство крестьян-дворохозяев выкупило арендуемые ранее зем.ли. Купленные участки были большей частью невелнки, 14-30 га, отдельные же достигали $50-60$ га.

В 1940 году Советская власть наделила безземельных и малоземельных крестьян землей. В 1949 году развернулось массовое колхозное движение эстонского крестьянства.

В обследованном районе в настоящее время имеется 7 колхозов; из них один является рыболовецким, один смешанным, остальные - сельскохозяйственными артелями. Қаждый из этих колхозов имеет 1200 . 2000 га земли. В составе каждого колхоза - от 51 до 90 семей. В колхозах быстро развивается животноводство, садоводетво и огородничество

Деревии, нанесенные на карту крестиками (рнс. 1), имели в прошлом смешанный состав населения. Назовем это население, по наименованию местного центра, ийсакскими эстонцами. Прнчудскне деревни Алайыэ и Уускюла являются русскими поселениями. Деревни Катасе и Куру имеют смешанное население.

Обследованная территория была заселена, по данным археологии, сравнительно поздно - лишь в XII веке н. э. В то время на этой территории появляются курганы новгородского типа, инвентарь которых носит в общем славянский облик, но проявляет при этом также и некоторые водьско-ижорские черты. По данным антропологин, обнаруженные 
в этих курганах скелеты представляют смешанный (русско-финский) тип.

По данным письменных источников XVI-XVII веков, в северной и средней части рассматриваемой территории преобладало эстонское население, между тем как на юге, по побережью Чудского озера, и на юговостоке жили русские В XVII веке русские упоминаются также на се вере данной территорин.

Согласно семейным традициям, часть ийсакских эстонщев считает себя преемниками исконного местного населения. Предки же другой части были, по преданию, прншельцы из бывших Псковской, Петербургской н других русских губерний, а также из Польши.

Собранные нами данные указывают, что русские сохранили свой язык дольше всего в деревне Порсково (ныне Вайкла), в других же деревнях они утеряли его раныше. Поэтому народная традишия помнит русских главным образом лишь в этой деревне.

Во всех ийсакских деревнях старшее поколение, лет 50 и старше, владеет русским языком. Одна часть населения усвоила его от родителей, другая же часть научилась ему в результате общения с соседним русским населением. Отдельные 70 - 80 -летние старикн предпочитают н в настояпее время говорить по-русски. Хутора, после выкупа их в собственность, вскоре были разделены в процессе наследования между сыновьями дворохозяев на большое число мелких участков. Такое явление было чуждо для остальной Эстонии, за исключением лишь юго-восточной части Эстонии, где оно явилось, повидимому, результатом русского влияния.

Разделом хуторов между сыновьями объясняется то, что до коллективизации в ийсакских деревнях целые группы соседних дворов прннадлежали однофамильцам. Среди них встречаем много фамилий русского происхождения: Карп, Субка, Федька, Нимвитский, Шевлинский, Заболотный, Давидов и т. д. В деревне Вайкла сохранилась отчасти еще и русская топонимика.

Такой же процесс перехода от одного языка к другому, только в обратном направлении, наблюдается и у населення в русскнх деревнлх Причудья. Так, в состав русского населения деревни Катасе вошло немало эстонцев. В русских рыбацких деревнях Алайыэ и Уускюла отдельные семьи помнят еще свое эстонское пронсхождение.

В обследованном районе прослеживаются, таким образом, два параллельыых процесса этнической ассимиляции. В прибрежных рыбацких поселениях, за исключением деревень Каукси и Куру, происходило и продолжается в наши дни обрусение поселившихся в этих деревнях эстонцев. На всей остальной территории происходил ббра́тный процесс, процесс постепенного воспринятия русскими эстонского языка.

Оба эти явления ускорнлись с развитием капиталистических отношений. Ранее других слоев смешанного населения ассимилировалась немногочнсленная зажиточная прослойка - сельская буржуазия, классо вые интересы которой побудили ее примкнуть к более многочисленной здесь эстонской буржуазии. Существенную роль сыграло также вероисповедание. Русские принуждены были, частично уже с XVII века, принять лютеранство. Лютеранская церковь содействовала несомненно тому, что русские крестьяне, принявшие протестанство, забывали свой язык и ассимилировались с эстонским населением.

Разнородный этнический состав нйсакского населения отражается и в его материальной - культуре.

Из земледельческих орудий следует отметить соху с изогнутой рос- 
сохой, неизвестную в остальной Эстонии. Соху называли тут как эстонским названием аркадра, так н русскнм - ругач, ругачулка, рыгачи.

В пище и ее приготовлении у населения Ийсаку, в особенности в деревне Вайкла-Порсково, проявляются некоторые русские черты. Приготовление производится нередко в печи. В ассортимент изготовляемых блюд входят разные виды пирогов, выпекаемых как из ржаной, так и нз пшеничной муки, с начинкой из мяса, брюквы или кислой капусты. Пироги начннялись также грибами и рыбой, что, совершенно очевндно, представляет русское явление. В прошлом в пище наблюдалось еще больше русских черт (употреблялась так называемая гуща, конопляное молоко, некоторые блюда из творога и т. д.).

В планировке поселений в настоящее время не наблюдается чнсто русских черт (за исключением деревни Алайыэ). О деревне Тяривере старики рассказывали, что в ней в середине XIX века дворы располагались по обе стороны широкой улицы, тесно один возле другого, причем жилые дома были обращены фронтоном к улице.

Планировка отдельных дворов в ийсакских деревнях та же, что и в остальной Эстонии. Постройки размешаютея обыкновенно вокруг открытого просторного прямоугольного двора. Однако в связи с разделом хуторов между наследниками этот план подвергался изменениям. Двор застранвался постройками младших братьев, становился более тесным и терял свою прежнюю форму (рис. 2).

Жилые дома обычно довольно просторны. Они нерёдко обшиты тесом и окрашены. Окна часто обрамлялись досками, окрашенными в синий нли белый цвет.

Из технических строительных особенностей отметим еще так называемый жграненый» угол, который сохранился в некоторых старых домах типа жилой риги и во многих старых клетях (рис. 3). У старых клетей крыша построена без стропил, она опирается на самцы, т. е. на бревенчатый фронтон. Такие постройки наблюдаются у русского населения Причудья, такого типа фронтоны характерны и для Белоруссии, для Новгородской области, а также встречаются у карельских построек.

На всей обследованной территории, за исключением рыбацких деревень Алайыэ и Уускюла, старое жилье представляло из себя либо жилую ригу, либо было связано с ней. В то время как батраки, или так называемые єполуденки», в большинстве случаев жили в одной только риге, где сушили и даже молотили хлеб, дворохозяева обычно имели дома, состоявшие из риги с двумя каморами. С ростом местной деревенской буржуазни появились к конщу прошлого столетия отдельные еще более просторные дома. $\mathrm{Y}$ середняков же жилой дом состоял и позже из риги, гумна и $1-2$ каморок, объединенных под одной крышей. Среди домов прослеживаются два разных типа. Первый характерен тем, что в нем каморы непосредственно примыкают к риге. Этот тип встречается в коренных эстонских деревнях, а также в деревнях ийсакских эстонцев. Второй тип жилища был, согласно воспоминаниям стариков, прежде общим в деревнях с полурусским населением, как например, в Вайкла-Порсково и Тяривере. Он встречается также в Иыуга, Колдамяэ и даже в Куру и Каукси. Отличительной чертой этого типа жилищ является то, что он имел между каморами и ригой длинное узкое помещение, называвшееся в прошлом сенями, превратившееся позднее в кухню (рис. 4) Из сеней одна дверь вела в рей - ригу, другая в жилую комнату избу. В деревне Тяривере указанный коридор назывался обицим.

В изучаемом районе жилые дома стали строиться отдельно от риги сравнительно рано, уже в $1870-1880$ годы.

На побережье Чудского озера в русских деревнях дома только рус- 
ского типа. Они состоят нз избы и сеней. К дому прнстроен крытый двор. Русский тип домов восприняли частично и проживающие в причудских деревнях эстонщы.

На всей обследованной нами территории новые постройки очень часто имеют одну русскую черту: у них доски фронтона поставлены «в елочку», а под фронтоном проходит узкий карниз или так называемый «нижний козырек». В других районах Әстонии мы этого, в особенности козырька под фронтоном, не встречаем.

Жилые помешения в Ийсаку отличаются чистотой. Пол преобладает некрашенный, однако он чисто вымыт и покрыт, как обычно в русских нзбах, половиками. Иногда в углу комнаты имеется полочка. В отдельных домах в углу большой комнаты стоит низкий шкаф с двумя свечами на нем. Это, повидимому, воспоминание о бывшем «большом» угле, который украшался в ийсакских домах еще в начале этого столетия, даже в лютеранских семьях.

Характерную особенность описываемых домов более позднего времени составляют их печи (рис. 6). Почти во всем обследованном районе печи имеют лежанку, называемую lesku, lezenka. Лежанка появилась в конце прошлого столетия. Отметим, что вьюшка в Ийсаку имеет русское название (juška).

Риги встречаются трех типов: первый тип риги отличается тем, что ее задняя боковая-стена является продолжением стены гумна, с передней же стороны рига у́же, так что крыша тут образует навес. У второго типа рига с обеих сторон у́же гумна. Рига третьего типа характеризуется тем, что она имеет одинаковую ширину с гумном.

У большинства риг колосники, грядки, расположены двумя ярусами, что характерно только для восточных районов Эстонской ССР.

Большинство старых клетей отличается гранеными углами и крышей на самцах. Клети имеют большей частью определенный размер, $4,2 \times 5$ м. Отдельные клети имеют выступающий вперед фронтон (рис. 7). Такие же клетн с выступающим фронтоном известны в Карелии. Этот тип клети встречается, по данным Этнографнческого музея АН ЭССР, также на юго-востоке Әстонии.

Народная одежда нйсакского населения показывала много русских черт. В ней прослеживались также отдельные водьско-ижорские элементы.

Изложенный материал показывает, что мы здесь имеем дело со своеобразной этнической группой населения, нмеющей свою продолжительную историю, свои особенности в хозяйстве, материальной культуре, а также в языке и фольклоре.

Археологические, исторические и этнографические данные позволяют проследить в данном районе несколько культурных и этнических наслоений. Археологические и антропологические материалы позволяют говорить о существовании на данной территории в XII-XIII веках смешанного русско-финского (водьско-ижорского) населения. Позже, в XIVXVII веках сюда стали проникать с севера эстонцы; одновременно, повндимому, продолжался и прилив русско-финского населения с востока.

В XVIII-XIX веках, особенно после Северной войны, в Ийсаку проникают новые русские пришелышы, которые укореняются главным образом в Порскове-Вайкла. В связи с этим в этот период в культуре местного населения усиливается русское влияние. Русские, основным занятием которых было земледелие, переняли к концу XIX века эстонский язык. В рыбацких же поселениях русские сохранили свой язык.

Собранные материалы показывают также, как прн капитализме взаимоотношения между различными национальностями в обследованном 
районе отравлялись буржуазно-националистической пропагандой. С восстановлением в Әстонии советского строя их взаимоотношения коренным образом изменились. Восторжествовала идея равноправия всех национальностей. Русских и эстонцев связывает в одну дружную семью единство интересов в социалнстическом труде. В описываемом районе имеется, как уже отмечалось, два колхоза со смешанным, русско-эстонским населением. Совместная работа в этих сельскохозяйственных артелях ведет к теснейшему взанмному общению представителей обоих народов, чему в значительной мере содействует знание старшим эстонским поколением русского языка. Посещая совместно школу, участвуя совместно в многочисленных кружках самодеятельности и в хорах, где поются русские и эстонские песни, колхозная молодежь обеих национальностей сближается не только в своем колхозе, но и в пределах сельсоветоз. В ббщественный и семейный быт населения нйсакских деревень внедрились качественно новые отношения. Расцвет культуры русского и эстонского народов взаимно обогащает быт обеих нащнональностей, что ярко прослеживается также на их материальной культуре.

Изучению ийсакских эстонцев положено пока лишь начало. Эту работу следует продолжить, привлекая к ней также лингвистов и фольклористов. Дальнейшее комплексное изучение этой своеобразной группы населения даст, как можно надеяться, результаты, имеющие не только местный интерес, - они позволят сделать и некоторые более общие историко-этнографические выводы.

Ннститут истории

Академии маук Эстонской ССР
Поступила в редакщню $20 \mathrm{~V} 1953$ 